\title{
Interface Shear Strength of Geosynthetic Clay Liner (GCL) and Residual Soil
}

\author{
Mohd Izzuddin Zaini, Anuar Kasa, Khairul Anuar Mohd Nayan \\ Civil \& Structural Engineering, The National University of Malaysia, Bangi, 43600, Malaysia \\ E-mail: izzuddin86@gmail.com, anuar@eng.ukm.my,khairul@eng.ukm.my
}

\begin{abstract}
In this study, direct shear box with dimension of $100 \mathrm{~mm} \times 100 \mathrm{~mm}$ was used to determine interface shear strength of a GCL and compacted residual soil at optimum moisture content. The tests were carried out using dry GCL sample at shearing rate of $0.5 \mathrm{~mm} / \mathrm{min}$. Normal stresses used were between $100 \mathrm{kPa}$ to $300 \mathrm{kPa}$ to represent the depth of $20 \mathrm{~meters}$ of solid waste $\left(15 \mathrm{kN} / \mathrm{m}^{3}\right)$. The needle-punched GCL was tested for both sides, woven and non-woven. Results showed that the residual soil, classified as CL according to the Unified Soil Classification System (USCS) with a hydraulic conductivity of 7.05 to $5.54 \times 10^{-9} \mathrm{~m} / \mathrm{s}$, was suitable to be used as compacted clay liner (CCL). Test results on the interface shear strength of woven and non-woven GCL with residual soil in terms of internal friction angle were $33^{\circ}$ and $37^{\circ}$, respectively.
\end{abstract}

Keywords — Interface shear strength; geosynthetic clay liner (GCL); residual soil.

\section{INTRODUCTION}

Malaysia is a tropical country. More than $75 \%$ of the land in Peninsular Malaysia consists of residual soil. This soil has a low hydraulic permeability $\left(10^{-7} \mathrm{~m} / \mathrm{s}\right)$ and is suitable for use as compacted clay liner (CCL) for construction of landfill.

Geosynthetic clay liner (GCL) is usually used as a hydraulic barrier (i) at the base of landfill to prevent the flow of leachate into the surrounding soil and (ii) at the top of landfill as cover to reduce infiltration of rainwater into the waste deposit [1] [2]. GCL is used as an alternative to CCL because it has a very low hydraulic conductivity of water $\left(\mathrm{k}_{\mathrm{w}}\right.$ $<10^{-11} \mathrm{~m} / \mathrm{s}$ ) and the cost of installation can be considered cheap [3]. It is also used in combination with CCL to provide double protection for municipal solid waste (MSW). For hazardous landfills, GCL and CCL are used in combination with geotextile and geomembrane.

In a construction of landfills, slopes can not be avoided. The interface friction of GCL and soil must be high enough to sustain the load generated during the life of the facility [3]. The value of friction is important because a combination of soil adjacent to the geosynthetics or geosynthetics adjacent to geosynthetics can produce weak surface at which failure or sliding may occur [4].

Due to the importance of interface friction between GCL and soil on slope, a study on the interface shear strength was conducted. Results in terms of residual soil properties and interface shear strength of GCL and residual soil are presented in this paper.

\section{Methodology}

To determine the properties of residual soil, several tests were carried out such as (i) particle size distribution, (ii) Atterberg limit, (iii) specific gravity, (iv) compaction, (v) permeability, and (vi) direct shear strength. Table 1 shows the specifications of GCL used in this study according to the supplier.

TABLE I

GCL PROPERTIES

\begin{tabular}{l|l|l}
\hline \multicolumn{1}{c|}{ Material Properties } & Test Method & \multicolumn{1}{c}{ Value } \\
\hline Bentonite swell index & ASTM D 5890 & $24 \mathrm{~mL} / 2 \mathrm{~g} . \mathrm{min}$. \\
Bentonite fluid loss & ASTM D 5891 & $18 \mathrm{~mL}$ max. \\
Bentonite mass/sq. area & ASTM D 5993 & $4 \mathrm{~kg} / \mathrm{m}^{2}$ \\
Grab strength & ASTM D 4632 & $400 \mathrm{~N}$ \\
$\begin{array}{l}\text { Peel strength } \\
\text { Index flux }\end{array}$ & ASTM D 4632 & $65 \mathrm{~N}$ \\
$\begin{array}{l}\text { Permeability } \\
\text { Hydrated internal shear } \\
\text { strength }\end{array}$ & ASTM D 5887 & $1 \times 10^{-8} \mathrm{~m}^{3} / \mathrm{m}^{2} /$ \\
& ASTM D 5887 & $5 \times 10^{-9} \mathrm{~cm} / \mathrm{s}$ \\
& ASTM D 5321 & $24 \mathrm{kPa}($ typical $)$ \\
& & \\
\hline
\end{tabular}


Residual soil was compacted at optimum moisture content (OMC) of $13.9 \%$ and maximum dry density of $1875 \mathrm{~kg} / \mathrm{m}^{3}$. Compaction was done using CBR mould having a diameter of $151.5 \mathrm{~mm}$ and height of $127.5 \mathrm{~mm}$. The soil was compacted in three layers with a hammer height of $300 \mathrm{~mm}$ and 55 blows per layer to achieve maximum dry density. The soil was cut to the required sizes of $100 \mathrm{~mm} \times 100 \mathrm{~mm}$.

Direct shear test was conducted with the maximum horizontal displacement of $15 \mathrm{~mm}$ and a constant shearing rate of $0.5 \mathrm{~mm} / \mathrm{min}$. Dimension of the upper and lower shear box was $100 \mathrm{~mm}$ x $100 \mathrm{~mm}$. Normal stresses, $100 \mathrm{kPa}, 200$ $\mathrm{kPa}$ and $300 \mathrm{kPa}$ used in this study were to simulate the stresses due to $20 \mathrm{~m}$ height of landfill based on the assumption that the density of the wet waste was approximately $15 \mathrm{kN} / \mathrm{m}^{3}$ [2]. This test was conducted according to ASTM D6243-98 procedures [5].

After the test, shear stress versus displacement was plotted to determine the shear strength at failure for each value of normal stress. The value of shear strength at failure was plotted against the normal stress to obtain the values of friction angle and adhesion.

\section{RESUlTS AND DISCUSSION}

Fig. 1 shows the results of particle size distribution, while Table 2 shows the properties of the sedimentary residual soil. Fig. 2 shows a graph of shear strength based on the relationship between shear stress and normal stress. From the graph, it is estimated that the values of internal friction angle and cohesion of the residual soil are $36.1^{\circ}$ and 55.2 $\mathrm{kN} / \mathrm{m} 2$, respectively.

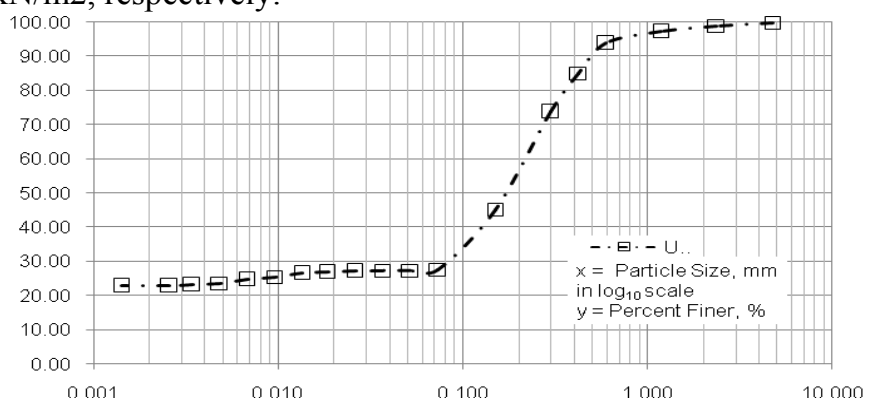

Fig. 1 Particle size distribution of residual soil

TABLE II

PROPERTIES OF RESIDUAL SOIL

\begin{tabular}{lr}
\hline Liquid limit, \% & 35.92 \\
Plasticity index & 19.12 \\
Optimum moisture content, \% & 13.89 \\
Maximum dry density, $\mathrm{kg} / \mathrm{m}^{3}$ & 1875.18 \\
Specific gravity, Sg & 2.57 \\
Hydraulic conductivity, $\mathrm{m} / \mathrm{s}$ & $7.05-5.54 \times 10^{-09}$ \\
\hline
\end{tabular}

Fig. 3 and 4 show the relationship between shear stress and displacement for the woven GCL and non-woven GCL when they are in contact with the compacted residual soil while Fig. 5 shows the comparison between the woven GCL and non-woven GCL in terms of interface shear strength at the time of the failure for certain normal stress value. In this analysis, the shear strength at failure is based on the peak shear strength.
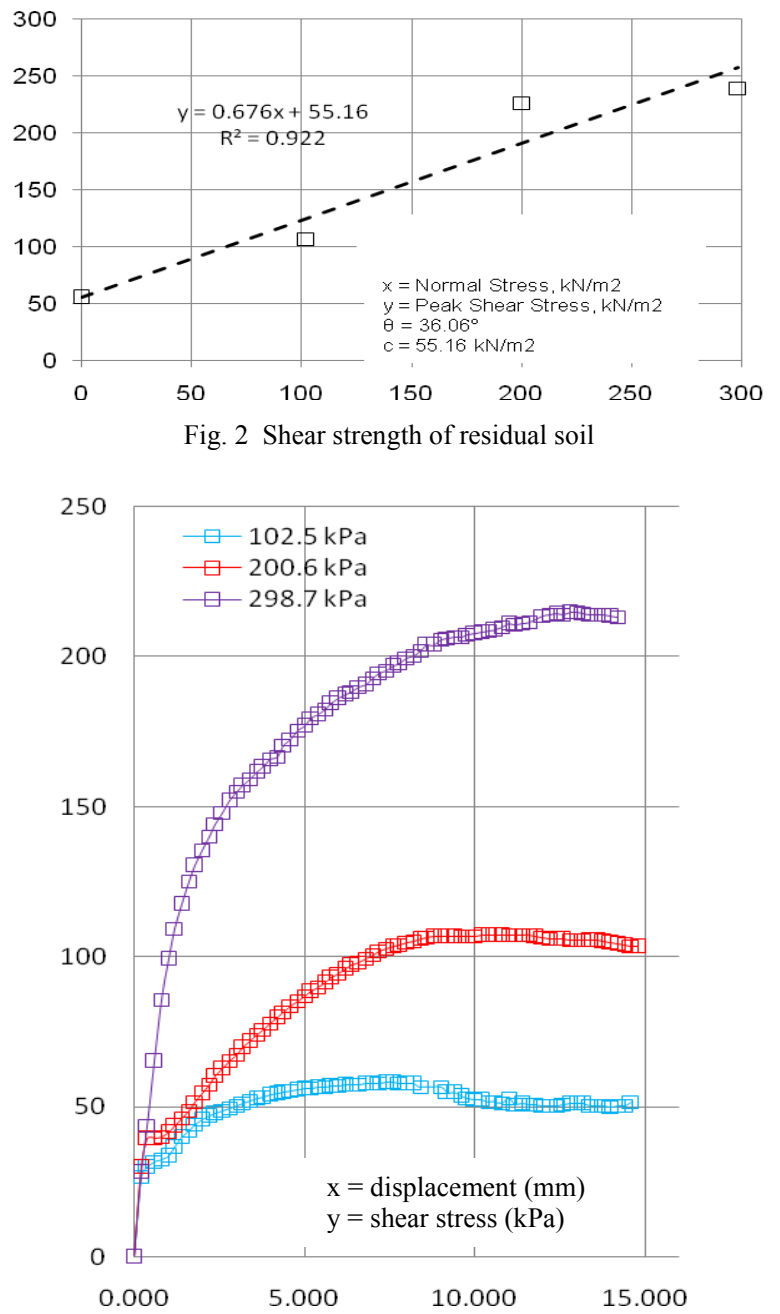

Fig. 3 Interface shear strength of woven GCL and residual soil

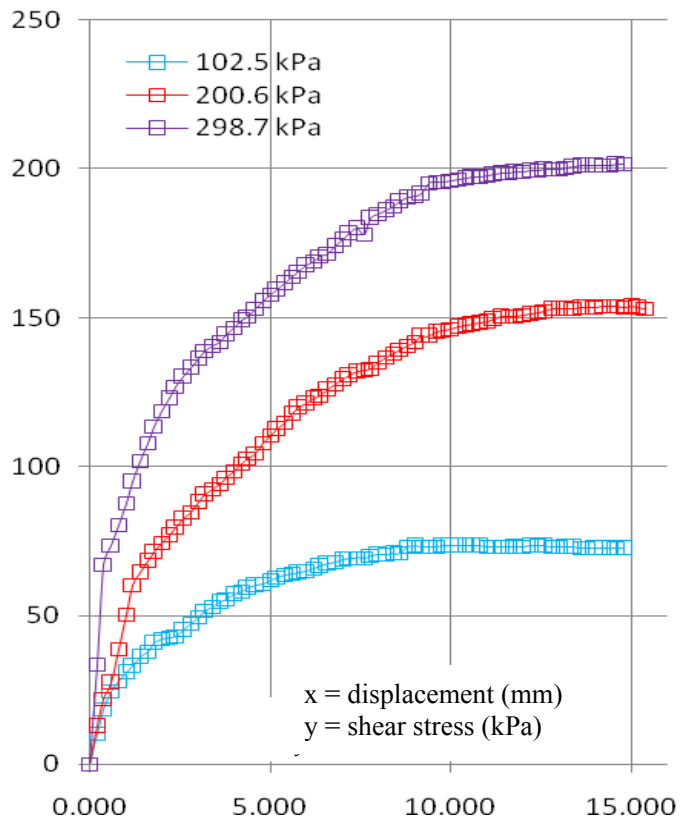

Fig. 4 Interface shear strength of non-woven GCL and residual soil

Hydraulic conductivity for the residual soil sample is in the range of 7.05 to $5.54 \times 10-9 \mathrm{~m} / \mathrm{s}$. To ensure that functions as a liner, the hydraulic conductivity of the CCL 
should be $\leq 1 \times 10-9 \mathrm{~m} / \mathrm{s}$ [6]. Thus, it can be said that the residual soil is suitable for use as CCL in landfills.

The interface friction angle of woven GCL is higher $\left(37^{\circ}\right)$ than that of non-woven GCL $\left(33^{\circ}\right)$ although the difference is small $\left(4^{\circ}\right)$. In terms of adhesion, it is not significant for woven GCL $(0 \mathrm{kN} / \mathrm{m} 2)$ while for non-woven GCL it is significant $(12.3 \mathrm{kN} / \mathrm{m} 2)$. Based on these observations, it can be said that the different textures of geosynthetics provide different interface shear strength values.

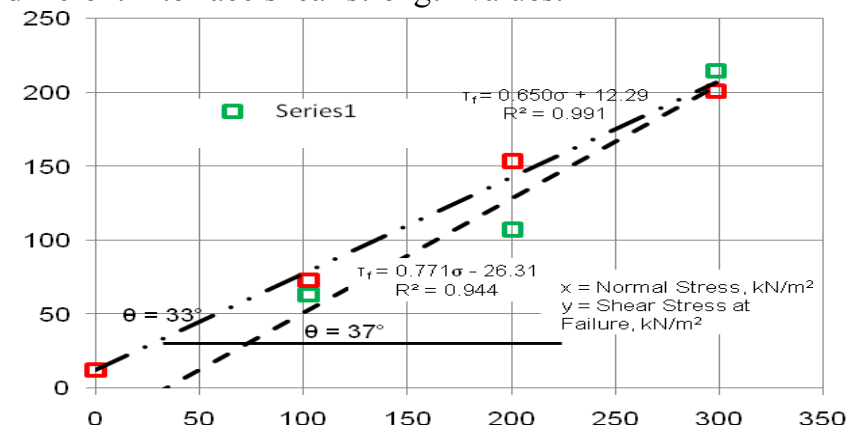

Fig. 5 Shear stresses vs. normal stresses

\section{CONCLUSIONS}

In summary, some observations were made after testing the basic properties of residual soil and interface shear strength of woven GCL and non-woven GCL with residual soil using $100 \mathrm{~mm} \times 100 \mathrm{~mm}$ shear box. It was found that (i) residual soil could be used as CCL for the construction of landfills because of the low hydraulic conductivity $(\mathrm{k}=7.05$ to $5.54 \times 10^{-9} \mathrm{~m} / \mathrm{s}$ ) and (ii) woven GCL has higher interface friction angle than the non-woven GCL.

\section{ACKNOWLEDGMENT}

The authors wish to thank the National University of Malaysia and the Ministry of Higher Education for their financial support under research grant UKM-KK-02FRGS0004-2007 and also Mas Kiara Group for providing the GCL.

\section{REFERENCES}

[1] Vukelic, A., A. Szavits-Nossan, and P. Kvasnicka, 2008. The influence of bentonite extrusion on shear strength of GCL/geomembrane interface. Geotextiles and Geomembranes, 26 (1): pp. 82-90.

[2] M. Kamon, S. Mariappan, T. Katsumi, T. Inui, T. Akai. 2008. LargeScale Shear Tests on Interface Shear Performance of Landfill Linear System. Proceeding of the 4th Asian Regional Conference on Geosynthetic: pp. 473-478.

[3] A. Bouazza. 2002. Geosynthetic Clay Liner. Geotextiles and Geomembranes 20 (1): pp. 3-17.

[4] H. D. Sharma and S. P. Lewis. 1994. Waste Containment Systems, Waste Stabilization and Landfill: Design and Evaluation. New York. John Wiley \& Sons, Inc.

[5] ASTM D6243, Standard Test Method for Determining the Coefficient of Soil and Geosynthetic or Geosynthetic and Geosynthetic Friction by the Direct Shear Method. American Society for Testing and Material International.

[6] Daniel D. E and Wu Y. K. 1993. Compacted Clay Liner and Covers for Arid Sites. Journal of Geotechnical Engineering. 119 (2). pp. 297 $-311$

[7] Head, K. H. 1988. Manual of Soil Laboratory Testing. Volume 2: Permeability, Shear Strength and Compressibility Test. London: Pentech Press limited.

[8] William, F.S. 2002. Foundations of Materials Science and Engineering, Third Eds., McGraw-Hill International. 